Article

\title{
Critical Business Ethics: Contributions and Challenges
}

Franz Giuseppe F. Cortez

\begin{abstract}
Various scholars have developed approaches to business ethics. In the secular sphere, the approaches include utilitarianism, deontology (Kantian), virtue, care, contractarianism, and stakeholder, among others. In the religious sphere, scholars explore what the major religions of the world have to say regarding the conduct of business. Thus, we encounter literatures on Hindu, Buddhist, Christian, Jewish, Arab, and Confucian approaches to business ethics.

In this paper, I will talk about a relatively new approach called Critical Business Ethics (CBE). This approach is mainly an attempt to bring Critical Theory of the Frankfurt School, structuralism, post-structuralism, and postmodernism among others, into the field of business ethics. However, it must not be seen as the approach to end all approaches but another way of looking at ethics and the conduct of business. In other words, the traditional approaches have already contributed a lot since the birthing of business ethics. The time is ripe to continue the march of reason and to not let business ethics be stunted or ossified.

I think that even if there were difficulties that a critical approach would confront, it would always remain a worthwhile endeavor. Thus, those who will teach Business Ethics and Social Responsibility must create opportunities and look for small pockets and openings when and where an alternative approach may thrive.
\end{abstract}

Keywords: ethics, business ethics, critical theory, critical business ethics

\section{Introduction}

$\mathrm{E}$ thics as a branch of philosophy is usually defined as the systematic study of right and wrong conduct. Business ethics is commonly understood as the study of ethical principles as applied in the business setting. It is considered as an applied ethics along with bioethics, journalism

(C) 2015 Franz Giuseppe F. Cortez

http://www.kritike.org/journal/issue 17/cortez december2015.pdf

ISSN 1908-7330

(cc) $\mathrm{BY}-\mathrm{NC}-\mathrm{ND}$ 
ethics, legal ethics, and others. Even within the sphere of business ethics, subbranches have sprouted, such as accounting ethics, financial management ethics, marketing ethics, advertising ethics, and human resources management ethics, among others.

Various scholars have developed approaches to business ethics. In the secular sphere, the approaches include utilitarianism, deontology (Kantian), virtue, care, contractarianism, and stakeholder, among others. In the religious sphere, scholars explore what the major religions of the world have to say regarding the conduct of business. Thus, we will encounter literature on Hindu, Buddhist, Christian, Jewish, Arab, and Confucian approaches to business ethics.

In this paper, I will talk about a relatively young approach called critical business ethics. A quick search at Google would not produce much literature since very few scholars use the term "critical business ethics." ${ }^{1}$ This approach is mainly an attempt to bring the Critical Theory of the Frankfurt School, structuralism, post-structuralism, and postmodernism, among others into the field of business ethics. ${ }^{2}$ Thus, with a plethora of intellectual patrons, critical business ethics is not $\underline{\text { Critical }}$ Business Ethics; that is, it is not a homogenous discourse.

At the outset, it must also be said that critical business ethics must not be seen as a messianic figure, the approach to end all approaches but another way of looking at ethics and the conduct of business. The other approaches have already contributed a lot since the birthing of business ethics. The time is ripe to continue the march of reason and to not let business ethics be stunted or ossified. After all, just like any other human sciences (Geisteswissenschaften), business ethics is "not a stable or uncontested discipline." 3

${ }^{1}$ Probably, it was first used, but only in passing, in ten Bos' and Willmott's 2001 article where they hint at "an alternative, critical business ethics that would acknowledge the manifold moral struggles of people in organizational contexts." See Rene ten Bos and Hugh Willmott, "Towards a Post-dualistic Business Ethics: Interweaving Reason and Emotion in Working Life," in Journal of Management Studies, 38:6 (September 2001), 790. This term was mentioned (again, in passing) in the introductory page of: Campbell Jones, Rene ten Bos, and Martin Parker, For Business Ethics: A Critical Approach (London: Routledge, 2005).

2 I follow the insight that critical theory does not only refer to the classical critical theory of the Frankfurt School and neo-Marxism but also to other discourses such as structuralism, post-structuralism, postmodernism, feminism, and psychoanalytic theory, among others. See Douglas Tallack, ed., Critical Theory: A Reader (New York: Harvester, 1995). See also Michael Peters, Mark Olssen, and Colin Lankshear, eds., Futures of Critical Theory: Dreams of Difference (Lanham: Rowman and Littlefield Publishers, Inc., 2003).

${ }^{3}$ Jones, ten Bos, and Parker, For Business Ethics, 8.

(C) 2015 Franz Giuseppe F. Cortez http://www.kritike.org/journal/issue 17/cortez december2015.pdf

ISSN 1908-7330 


\section{The "Critical" in Critical Business Ethics?}

It is necessary to clarify the sense of "critical" in critical business ethics because it can be argued that ethics is necessarily critical and that the function of business ethics is to bring critical reflections into the world of business. For example, Alpar Losoncz contends that "ethics always includes critical normative perspectives and polemical aspects and, according to this, critical approach is not supplement to business ethics, but a necessary component of it." 4 Then, Peter Dean even "offers a set of questions to guide decision-makers who are faced with difficult choices, then presents a decision-making template based on sound ethical theory and demonstrates how it may be used." 5

Without undermining the importance of sound reasoning, I have to note that the "critical" in critical business ethics does not only refer to logical and analytical abilities. ${ }^{6}$ To make business ethics more critical does not simplistically mean to harmonize ethical reasoning with the laws and principles of logic and epistemology. It is not confined to the dream of making the business ethics students, teachers, professionals, and practitioners more adept in finding the fallacious reasoning in ethical decision-making.

Rather, the demand of critical thought is "to think about things, to look at alternative perspectives, and in the end to make the world that we are familiar with look a little bit more strange than it usually does."7 To be critical is a constant practice of seeing the power relations embedded in ethical issues in business. Thus, more than an epistemological and logical category, critique is a social and political concept. Many years before Aristotle put an order into the Organon that he called Logic, Socrates was already thinking critically about the Greek polis. Socrates was the gadfly of Athens not for following the laws of Aristotelian logic but for problematizing the Athenian life.

The "critical" in business ethics may be aimed at the current practices of business and it may also be directed at how ethics is brought into the

\footnotetext{
${ }^{4}$ Alpar Losoncz, "Business Ethics as Critical Approach," in Society and Economy, 25:2 (2003), 139

5 F. Peter Dean, "Thinking Critically About Business Ethics," in Journal of College Teaching and Learning, 1:4 (2004), 1.

${ }^{6}$ For thorough discussions on the connotations of "critical," see the following: Nicholas Burbules and Rupert Berk, "Critical Thinking and Critical Pedagogy: Relations, Differences and Limits," in Critical Theories in Education, ed. by Thomas S. Popkewitz and Lynn Fendler (New York: Routledge, 1999); Stephen D. Brookfield, The Power of Critical Theory for Adult Learning and Teaching (New York: Open University Press, 2005); Irvin Peckham, Going North, Thinking West: The Intersections of Social Class, Critical Thinking, and Politicized Writing Instruction (Utah: Utah State University Press, 2010).

${ }^{7}$ Jones, ten Bos, and Parker, For Business Ethics, 1.
}

(c) 2015 Franz Giuseppe F. Cortez

http://www.kritike.org/journal/issue 17/cortez december2015.pdf

ISSN 1908-7330

(c) BY-NC-ND 
business sphere. Furthermore, for it to be an authentic critique, it must problematize and challenge the dominant discourses and then offer alternative discourses (not necessarily programs and systems) that are diametrically opposed to the said dominant discourses. It is "critical" because it looks into ethics whether it implicitly or explicitly, consciously or unconsciously, advocates the values and institutions of unbridled corporate capitalism.

\section{Main contributions of Critical Business Ethics}

\section{Critique of Conventional Business Ethics}

One way of understanding business ethics is to see it as a response of well-intentioned people to the evils brought about by capitalism. The prominent business ethicist, R. Edward Freeman comments that "business ethics was born in scandal" and "it seems to regenerate itself with each succeeding wave of scandal." ${ }^{8}$ Edward Wray-Bliss, a professor of business and management at Macquarie University, similarly observes that significant developments in business ethics scholarship usually happen especially during times when the business world confronts issues and dramatic changes. ${ }^{9}$ However, Wray-Bliss also argues that many forms of business ethics are simply "complicit in deception, serving to contain and deflect criticism from the institutions of capitalism, enabling business to bluff ethical, to present a caring front while carrying on exploitative and unethical practices as usual behind its back." 10 Engelbrecht, another scholar along the lines of critical business ethics, argues that through business ethics, ethics is subordinated to business as the former becomes a means to an end, "representing principles and practices convertible into profit in the long run." 11

And so, the first important contribution of critical business ethics is its pointed criticism of how the general ways of understanding and practice of business ethics are simply window-dressing and sugar-coating. Along the way, these ways of doing business ethics do not really tame the unbridled aspect of capitalist business. Rather, it is ethics itself that is tamed and that

${ }^{8}$ R. Edward Freeman, Foreword to Business Ethics and Continental Philosophy ed. by Mollie Painter-Morland, and Rene ten Bos (Cambridge: Cambridge University Press, 2011), xiii.

${ }^{9}$ Edward Wray-Bliss, "Business Ethics," in Key Concepts in Critical Management Studies, ed. by Mark Tadajewski, Pauline Maclaran, Elizabeth Parsons, and Martin Parker (Los Angeles: SAGE, 2011), 33.

${ }^{10}$ Wray-Bliss, "Business Ethics," 34.

${ }^{11}$ Schalk Engelbrecht, "Radical Business Ethics: A Critical and Postmetaphysical Manifesto," in Business Ethics: A European Review, 21: 4 (October 2012), 343.

(C) 2015 Franz Giuseppe F. Cortez http://www.kritike.org/journal/issue 17/cortez december2015.pdf

ISSN 1908-7330 
facilitates as well the "sharpening of the teeth of the tiger."12 It is ethics itself that has become an apologia to business in our capitalist society. ${ }^{13}$ Business Ethics and Corporate Social Responsibility have become tools for corporate branding and corporate image as more money is poured into the promotion of good acts than into the good acts themselves. ${ }^{14}$ "Ethics becomes a specific part of a business and marketing strategy."15 Values are subsumed by value. One is left to wonder whether business ethics truly helps in alleviating problems arising from business and economic interactions. Or does it only contribute to aggravating them? ${ }^{16}$ Indeed, conventional business ethics is so "interest-ed" that it ceases to be interested in ethics at all.

\section{Rethinking the meaning of "ethics" and the "ethical"}

The word "ethical" in the expression "ethical issues in business" would at once ring a bell and produce association with a plethora of examples: tax evasion, bribery, pollution, deceptive advertising, and many more. What the scholars of critical business ethics observe, however, is the narrowness of what counts as the ethical. ${ }^{17}$ When some issues are labeled as "ethical issues in business," what happens intentionally or unintentionally is that other things are relegated to be not "ethical" and to be not "issues" at all. Regarding this, Jones, Parker and ten Bos ask the following questions: Is routine work, which is not satisfying and not meaningful at all, not an ethical issue in business? When a company with shareholders gives some of the profits it has made to investors who have not been involved in producing the value, this is seen as a reward for risk. But why should the bulk of the surplus generated by workers be given to someone else who almost certainly already has a lot of money in the first place? Why do poor nations have to export food when their own populations are starving? Why are third world workers paid so little to make things that are sold for huge profits in the first world? ${ }^{18}$

This myopic understanding of ethics may lead one to also narrowly understand business ethics as simply and simplistically the application of

\footnotetext{
12 Piet Naude, "In defence of partisan justice: What can African business ethics learn from John Rawls?" in African Journal of Business Ethics, 2:1, (2007), 40-44.

${ }^{13}$ Engelbrecht calls the present business ethics as "apologetic business ethics." See Engelbrecht, "Radical Business Ethics," 342.

${ }^{14}$ Ajnesh Prasad and Albert J. Mills, "Critical Management Studies and Business Ethics: A Synthesis and Three Research Trajectories for the Coming Decade," in Journal of Business Ethics, 94 (2010), 231.

${ }^{15}$ Martin Parker, "Business, Ethics and Business Ethics: Critical Theory and Negative Dialectics," in Studying Management Critically, ed. by Mats Alvesson and Hugh Willmott (London: SAGE Publications, 2003), 202.

${ }^{16}$ Engelbrecht, “Radical Business Ethics," 340.

${ }^{17}$ Jones, ten Bos, and Parker, For Business Ethics, 5.

${ }^{18}$ Ibid., 5.

(c) 2015 Franz Giuseppe F. Cortez http://www.kritike.org/journal/issue 17/cortez december2015.pdf ISSN 1908-7330
} 
ethical principles into the field of business. But from a critical point of view, Wray-Bliss suggests that business ethics can also be understood "as the conceptualization, critique and promotion of ethics as it relates to business and organizational behavior."19 This critical perspective leads one to see ethics not as a closed and finished system wherein day-to-day practices are supposed to fit in. Rather, ethics involves thinking and re-thinking, denaturalizing and problematizing. The critical perspective opens as well to the possibility of "ethics-talk" that is not only centered on moral issues in business but also including the way in which business people who are "generally non-philosophers, engage with ethical and moral matters and issues." 20 Thus, scholars of critical business ethics take to task when bureaucratization of the workplace is taken as a given or when neoliberal ideology is considered natural.

\section{Persistent Critique of Economic Globalization}

Critical business ethics is highly critical of economic globalization that is mainly based on neoliberal economic policies, "which assume that unregulated markets will bring prosperity to all." 21 Along this understanding of critique, Lippke's 1995 work entitled Radical Business Ethics suggests a business ethics that is "explicitly linked to an egalitarian theory of justice, and critical of the basic structure of advanced capitalist societies." 22 For his part, Engelbrecht imagines a radical business ethics that "refuses to believe that free-market capitalism represents the logical and desirable (final) destination of a linear and progressive history. Instead, free-market capitalism is regarded as a contingent and historical phenomenon, enjoying no necessary historical status." 23 Meanwhile, Jones, ten Bos, and Parker allot a whole chapter of their textbook on business ethics for an analysis of global capital and its concrete implications to business ethics. ${ }^{24}$

What these scholars have accomplished is a way of doing business ethics that cannot sit comfortably with neoliberal economic arrangements. At least on this line of thought, these critical scholars find resonance with what Pope Francis criticizes as the economy of exclusion. The Pope says:

${ }^{19}$ Wray-Bliss, "Business Ethics," 33.

${ }^{20}$ Rene ten Bos and Hugh Willmott, "Towards a Post-dualistic Business Ethics: Interweaving Reason and Emotion in Working Life," in Journal of Management Studies, 38:6 (September 2001), 770.

${ }^{21}$ Jones, ten Bos, and Parker, For Business Ethics, 96.

${ }^{22}$ Richard Lippke, Radical Business Ethics (Lanham, MD: Rowman and Littlefield, 1995). Cited in Engelbrecht, "Radical Business Ethics," 344.

${ }^{23}$ Engelbrecht, "Radical Business Ethics," 346.

${ }^{24}$ Jones, ten Bos, and Parker, For Business Ethics, 96-111.

(C) 2015 Franz Giuseppe F. Cortez http://www.kritike.org/journal/issue 17/cortez december2015.pdf

ISSN 1908-7330 
. . . some people continue to defend trickle-down theories which assume that economic growth, encouraged by a free market, will inevitably succeed in bringing about greater justice and inclusiveness in the world. This opinion, which has never been confirmed by the facts, expresses a crude and naïve trust in the goodness of those wielding economic power and in the sacralized workings of the prevailing economic system. ${ }^{25}$

Cardinal Luis Antonio Tagle, a Filipino Catholic bishop, refers to this as an economy that grows vertically (benefitting those who are already welloff from the beginning) but never expands horizontally (leaving behind the poor and marginalized). ${ }^{26}$

\section{Diversifying the Philosophical Horizons}

It has been observed by some business ethics scholars that the philosophical foundations of Business Ethics are generally centered on utilitarianism, deontology, and virtue ethics. R. Edward Freeman claims that even if this domination by Anglo-American analytic philosophy was beneficial especially during the birth of business ethics as an academic discipline, there is a need to go beyond Mill, Kant, and Aristotle. Freeman says:

For too long, business ethics has been the captive of Anglo-American analytic philosophy. Ethical theory to most business ethicists means the traditional trifecta of consequentialism (usually utilitarianism), deontology (usually Kant), and virtue ethics (usually Aristotle). While this has been quite useful in the academic beginnings of the field, it is high time that we begin to connect these now traditional texts and arguments in business ethics with other traditions in the humanities. ${ }^{27}$

\footnotetext{
${ }^{25}$ Francis, Evangelii Gaudium, Apostolic Exhortation of the Holy Father Francis to the Bishops, Clergy, Consecrated Persons, and the Lay Faithful on the Proclamation of the Gospel in Today's World (2013), §54.

${ }^{26}$ In a television interview, this is what Tagle originally said: "Ekonomiyang lumalago, subalit hindi lumalaganap."

${ }^{27}$ Freeman, Foreword to Business Ethics and Continental Philosophy, xiii.

(c) 2015 Franz Giuseppe F. Cortez http://www.kritike.org/journal/issue 17/cortez december2015.pdf ISSN 1908-7330 
Jones, ten Bos, and Parker go a step further by arguing that business ethics scholars deliberately discount or even misrepresent $20^{\text {th }}$ century philosophies and philosophers. According to these three authors:

Despite the fact that ethics has been hotly debated in philosophy throughout the twentieth century and has been one of the major sources of philosophical reflection up to the close of the millennium, the discipline of business ethics has insulated itself from these developments, either ignoring them altogether or misrepresenting them so that it looks as if twentieth century philosophy has nothing interesting to say about ethics. ${ }^{28}$

Hence, critical business ethicists explore atypical philosophical characters in the field of Business Ethics, going beyond discourses centered on Mill, Kant, and Aristotle. Thus, it should not be strange anymore to talk about Marx, Adorno, Honneth, Arendt, Levinas, and Derrida, among others.

For example, Campbell Jones suggests how Levinas can help in our attempt to understand ethical relationship with the Other going beyond the traditional essentialist definition of ethics. ${ }^{29}$ Mollie Painter-Morland explains how Derrida helps us to take a critical stance regarding issues such as gift giving (bribery?) or the limits of constructing step-by-step menu in ethical decision-making. ${ }^{30}$ Axel Honneth's theory of recognition was used by Gazi Islam to explain the ethical issues of reification and recognition in human resources management. ${ }^{31}$ Jones, ten Bos, and Parker deployed Marx's notion of commodity fetishism for a deeper awareness of the dangers of global capitalism.32 Martin Parker deployed Theodor Adorno's negative dialectics for a critical understanding of business and ethics. ${ }^{33}$ Clegg, Kornberger, and

\footnotetext{
${ }^{28}$ Jones, ten Bos, and Parker, For Business Ethics, 3.

${ }^{29}$ Campbell Jones, "As if Business Ethics Were Possible, 'Within such Limits . . .'” in Organization, 10:2 (2003), 223-248.

${ }^{30}$ Mollie Painter-Morland, "Moral Decision-making," in Business Ethics and Continental Philosophy, 117ff.

${ }^{31}$ Gazi Islam, "Ethical Issues of Reification and Recognition in HRM: A Critical Social Theory Perspective," in Business Ethics: A Critical Approach, Integrating Ethics Across the Business World, ed. by Patrick O'Sullivan, Mark Smith, and Mark Esposito (London: Routledge, 2012), 7485.

32 Jones, ten Bos, and Parker, For Business Ethics, 103-108.

33 Parker, "Business, Ethics and Business Ethics: Critical Theory and Negative Dialectics," $197 \mathrm{ff}$.
}

(c) 2015 Franz Giuseppe F. Cortez http://www.kritike.org/journal/issue 17/cortez december2015.pdf ISSN 1908-7330 
Rhodes - to comprehend the ethical issues involved in a modern bureaucratic organization-positioned Arendt's notion of the "banality of evil." ${ }^{34}$

\section{Critique of the Technicization of Ethics}

The business field, usually assumed as a scientific field and thus, embraces rationality, technique, and objectivity, has become hospitable to a tradition of philosophizing that is also particularly interested in technique and science-that is, analytic philosophy. Painter-Morland and ten Bos note that "business ethics is firmly rooted in the analytic tradition" and "embraced the analytic agenda." 35 Similarly, Parker observes that "the moral philosophies which are incorporated largely comprise the classics of the analytical canon." 36 This is not totally bad at all as business ethicists explored the normativities of business practices, assisted in the formulation of codes of ethics, and advanced novel ideas for a deeper understanding of the complexities of business relations.

However, along the way as analytic philosophy is centered, other philosophical traditions are marginalized. Painter-Morland and ten Bos argue that the continental philosophers are relegated to the background. ${ }^{37}$ And more seriously, business ethics in general falls prey to what Jürgen Habermas calls technocratic rationality and thus surrenders its emancipatory potential. Ethics is now deployed as a tool for solving business and management problems. The positivist process is exemplified by Martin Parker in these words: "The management decision-maker collects the evidence, models a set of potential algorithms, and then makes a decision on what actions should be taken." 38

This technicization of ethics becomes clearer in Painter-Morland's essay entitled "Moral Decision-Making." Here, she notes that ethics becomes "a mere device that is 'instrumental' in management decision-making. It seeks to make ethics an easy set of rules, instead of confronting the decisionmaker with some real ethical problems. Furthermore, it pretends that the right recipe will always lead to the perfect result....There is blind faith in the process and in the instrumental use of moral reasoning...." 39

Taking its cue from Jacques Derrida's notion of undecidability, Painter-Morland explains: "If decisions were in fact foregone conclusions

\footnotetext{
${ }^{34}$ S. Clegg M. Kornberger, and C. Rhodes, “Organizational ethics, decision making, undecidability," in Sociological Review, 55:2 (2007), 393-409.

${ }^{35}$ Painter-Morland and ten Bos, "Introduction: Critical Crossings," in Business Ethics and Continental Philosophy (Cambridge: Cambridge University Press, 2011), 7.

${ }^{36}$ Parker, "Business, Ethics and Business Ethics," 200.

${ }^{37}$ Painter-Morland and ten Bos, "Introduction: Critical Crossings," 7.

${ }^{38}$ Parker, "Business, Ethics and Business Ethics," 201.

${ }^{39}$ Painter-Morland, "Moral Decision-making," 127.

(C) 2015 Franz Giuseppe F. Cortez http://www.kritike.org/journal/issue 17/cortez december2015.pdf ISSN 1908-7330
} 
that could be identified via a set of steps or rules, we could program computers to make those decisions for us." 40 Unfinished-ness and undecidability are real elements of ethical decision. Undecidability, as Derrida would explain, does not mean indecisiveness. Not that we will not decide but we should always maintain a certain level of discomfort in our decisions. The specter of undecidability must always haunt us. "A decision is always something that has to be pondered over time. It challenges us to an ongoing process of questioning, wondering whether we could not have done better." 41 Retrenchment may be necessary, legal, and ethical. But should the decision-maker sleep soundly? Or should he wonder whether he could have done better? As Derrida would say, the decision is always haunted by what it excludes.

\section{Dynamic Interaction between the Individual and the Social}

Critical business ethics questions conventional business ethics because of the latter's tendency to individualism. "Individualistic explanations of social action focus exclusively, or largely, on the characteristics of individuals, and ignore or downplay the role of social context." 42 Admittedly, the individual (the erring businessman, CEO, manager, or employee) must bear the burden of responsibility.

But what is the role of social structures for their questionable conduct? Why do they evade taxes and pay bribe? "Sometimes we also need to criticize social structures and arrangements, and to see the way that those structures influence action, making some types of action possible and others impossible. If we want to explain the scandals associated with business, it is important that we see both the individuals responsible for certain choices and the context in which their actions took place." 43 After all, these individuals are people of good reputation graduating from the best schools in town.

Thus, the question is not only-Is my action ethical or unethical?but also-What structural and societal factors led me to these unethical decisions? We criticize the individual but we must also problematize the society that binds his/her ethicality. We do not just talk about whether child labor is ethical or unethical using the perspectives of Mill, Kant, Rawls, and Aristotle. We also take a closer look at who are really privileged and who are really hurt when the ethics of child labor is reduced to deontological analysis or utilitarian calculations. In the concrete, we become more critically curious why defiant Bolivian child workers passionately and violently opposed the

${ }^{40}$ Ibid., 127.

${ }^{41}$ Ibid., 138.

42 Jones, ten Bos, and Parker, For Business Ethics, 4.

${ }^{43}$ Ibid., 4.

(C) 2015 Franz Giuseppe F. Cortez http://www.kritike.org/journal/issue 17/cortez december2015.pdf

ISSN 1908-7330 
law that will ban child labor, making one 13-year-old Bolivian protester exclaim: "You cannot leave [us] without a job-those of us [whose] life has given no other choice but to work." 44 Thus, we do not just ask: Is it really morally right to categorically ban child labor? But we also contemplate: Who is really privileged and who is really deprived when child labor is uncritically banned?

To take another example, ethical judgment must not be confined to judging whether bribery is moral or immoral. We are encouraged to look at the whole system that forces one to bribe or that tolerates a culture of bribery. Copyright infringements must be seen not just as an individual offense against law and morality but also as a phenomenon that is inevitably linked with how the society is arranged economically and politically and how certain discourses are legitimized. ${ }^{45}$ A serious misconduct in the company cannot be myopically seen as an individual fault or an isolated glitch in the running of a well-oiled machine. (There is no problem with the system; there is a problem with the person.) The corporate individual is submerged in a corporate culture and structure that significantly affects the way he/she thinks, behaves, and acts. How difficult is it for you to be virtuous and just in a corporate culture that is not conducive to virtue and justice? How difficult can it be to live a good life in a wrong state of affairs? ${ }^{46}$

\section{Challenges to Critical Business Ethics}

\section{Marxophobia, Marxistomania, Marxolescence}

One of the many theoretical bases of critical business ethics is the Critical Theory of the Frankfurt School. Furthermore, it originates from scholars who are usually affiliated with Critical Management Studies. Brought into the realm of educational theorizing, the tradition of Critical Pedagogy would not have much difficulty in embracing critical business ethics as well. These mentioned intellectual traditions (critical theory, critical management studies, critical pedagogy) are essentially anchored on Marxian

\footnotetext{
${ }^{44}$ Patricia Mallen, "Bolivia's Bill to Ban Child Labor is Opposed by Child Workers," in International Business Times (28 December 2013), <http://www.ibtimes.com/bolivias-bill-banchild-labor-opposed-child-workers-president-evo-morales-delays-vote-january $>, 23$ October, 2014.

45 Two studies come to mind: Helen Nissenbaum, "Should I Copy My Neighbor's Software?" in Computers, Ethics, and Social Responsibility, ed. by D. Johnson and H. Nissenbaum, (New Jersey: Prentice Hall, 1995); W. R. Swinyard, H. Rinne and A. Keng Kau, "The Morality of Software Piracy: A Cross-Cultural Analysis" in Journal of Business Ethics, 9 (1990): 655-664.

46 "Wrong life cannot be lived rightly." Theodor Adorno, Minima Moralia. Quoted in Stephen Eric Bronner, Critical Theory: A Very Short Introduction (New York: Oxford University Press, 2011), 74.

(c) 2015 Franz Giuseppe F. Cortez http://www.kritike.org/journal/issue 17/cortez december2015.pdf ISSN 1908-7330
}

(c) BY-NC-ND 
(not necessarily Marxist) analysis of the society and political economy. In other words, critical business ethics is essentially Marxian and generally in the leftist wing.

The first challenge, therefore, concerns what Peter McLaren would call as the ongoing knee-jerk Marxophobia, an irrational fear of engaging with Marx. ${ }^{47}$ As for the case in the Philippines, this was also noted by Paolo Bolaños when he says that one of the reasons for the crisis of appropriating critical theory in the Philippines is the fear of materialist/Marxist philosophy branded inaccurately as a font of horrifying and violent political tendencies. ${ }^{48}$ In relation to this, I further contend that this Marxophobia is rooted in a certain kind of Marxistomania, that is, an obsession to equate Marx with the Marxists. ${ }^{49}$ Thus, scholars of the critical approach to business ethics must continue to develop discourses that insulate the Marxian thoughts (not necessarily Marxist thoughts) from the accusations of totalitarianism and authoritarianism.

Coupled with Marxophobia is Marxolescence or the deemed obsolescence of Marx. Any discourse that implores Marx is usually subject to doubt at best and to outright disregard at worst. Thus, discourses must also be developed that show the paradoxical movements from outdated communist experiments to relevant Marxian revivals, for as long as unbridled capitalism is in business, the specter of Marx continues to haunt the contemporary society. ${ }^{50}$

\section{The Issue of Pedagogy}

Another challenge is connected to the unresolved question of who should teach business ethics - the teacher who is trained in philosophy (but usually lacks business acumen) or the business practitioner and business professional (but usually lacks training in philosophy). More than 10 years ago, the American business ethics educator Ronald Sims suggested a kind of synergy among various fields. He said that business ethics teachers must be willing to cross the boundaries of discipline. ${ }^{51}$ It is because by nature,

\footnotetext{
${ }^{47}$ Peter McLaren, Life in Schools: An Introduction to Critical Pedagogy in the Foundations of Education, 3rd ed. (New York: Longman, 1997), 172.

${ }^{48}$ Paolo A. Bolaños, "What is Critical Theory? Max Horkheimer and the Makings of the Frankfurt School," in Mabini Review, 2:1 (2013), 14-15.

${ }^{49}$ This claim is not yet supported by a scholarly research but by a personal observation that many people, upon hearing Karl Marx, at once relates him with the human rights violations and terrors happening in communist countries.

${ }^{50}$ See Terry Eagleton, Why Marx was Right? (New Haven: Yale University Press, 2011),

2.

${ }^{51}$ Ronald Sims, Teaching Business Ethics for Effective Learning (Connecticut: Quorum Books, 2002), 59ff.
}

(C) 2015 Franz Giuseppe F. Cortez http://www.kritike.org/journal/issue 17/cortez december2015.pdf ISSN 1908-7330 
business ethics is a multidisciplinary and interdisciplinary field. One cannot uphold philosophy while undermining economics, politics, psychology, accounting, law, management, and other relevant fields in business activities. On the other hand, one cannot easily replace the teacher trained in the discipline of philosophy with the teacher trained in the business school or with a business practitioner.

This time, I further contend that although Ronald Sims already hints at the difficulty of the interdisciplinary approach when applied in the concrete aspect of educational management, the introduction of the critical approach in the business ethics classroom poses further difficulties and complexities. Can many business practitioners relate with the musings of critical business ethics scholars? In fact, can they sympathize with it so that they are willing to bring it into the level of pedagogy?

\section{Tendency to Esotericism}

Another challenge concerns the language of critical theories in general and critical business ethics in particular. In a field such as business, the place of theories is usually held in suspicion and the discussions about theories end up with being "unnecessarily complex and inaccessible" and "function as a form of exclusionary practice with the effects of producing a problematic expert elitist academic authority and culture." 52 Teachers and students of business ethics would take extra effort in understanding and appreciating unconventional sources from Marx to Adorno, to Foucault, and to Derrida. Of course, the undertaking is not impossible but it is extremely difficult. Scholars from the field of critical business ethics are challenged to produce works that are not soaked in elitist, exclusive, impenetrable, theoretical, abstract, and ambiguous terms and concepts. In fact, one of the accusations against critical pedagogues is the difficulty of the language they are using. ${ }^{53}$

I support the view that those in the field of philosophy must not anymore hide behind the cloak of esoteric language that makes them detached from the concerns of ordinary people. Bringing in the empirical method especially in applied ethics such as Business Ethics may be a small step in making philosophy more relevant, of course, without compromising the speculative and critical aspect of the philosophical act.

${ }^{52}$ Edward Wray-Bliss, "Abstract Ethics, Embodied Ethics: The Strange Marriage of Foucault and Positivism in Labour Process Theory," in Critical Management Studies: A Reader, ed. by Christopher Grey and Hugh Willmott (Oxford: Oxford University Press, 2005), 384.

${ }^{53}$ For example, see Lois Christensen and Jerry Aldridge, Critical Pedagogy for Early Childhood and Elementary Educators (Dordrecht: Springer, 2013), 13.

(c) 2015 Franz Giuseppe F. Cortez http://www.kritike.org/journal/issue 17/cortez december2015.pdf ISSN 1908-7330

(c) BY-NC-ND 
Business Ethics is one of those fields that would gain a lot from the methods of science. Hannah Arendt's notion of banality of evil was corroborated by the social psychologist Stanley Milgram's scientific experiment on obedience to authority. ${ }^{54}$ Robert Jackal's brilliant admixture of ethnological critique and empirical method of the ethical culture of corporate managers confirms the speculations of Max Weber. ${ }^{55}$ George Ritzer's extensive empirical and anecdotal data gathering on the phenomenon of McDonaldization is similarly an ode to Weber's rationalization thesis. ${ }^{56}$ At present, scholars do not fail to cite Jackal, Milgram and Ritzer alongside Weber and Arendt when talking about the ethics of a bureaucratized society. Horkheimer himself endorses the crisscrossing of philosophy with social sciences when he envisioned a social philosophy that is multidisciplinary and interdisciplinary in approach. ${ }^{57}$

Having said this, it must also be noted that approaching the empirical necessitates careful and calculated steps lest those who claim to embrace the critical approach may fall into the traps of what they are supposed to critique.

\section{Openness to Alternatives}

When esoteric language is coupled with hazy alternatives, the drumbeaters of the critical approach would have the tendency to be just noisy gongs and clanging cymbals. Coupled with passionate and justified criticisms of the present economic and political setup, scholars of critical business ethics must explore and popularize the alternatives. Will they endorse alternative globalizations? ${ }^{58}$ What about the potentials of social entrepreneurship, social businesses, b-corporations, socially responsible investments, and solidarity economy? Will critical business ethics not appear rigid vis-a-vis business models inspired by religious convictions, such as the Economy of Communion?

Are critical business ethics scholars willing to listen to the sincere attempts to put a human face on capitalism? Is the very internal logic of capitalism the problem? ${ }^{59}$ And if this is really the problem, can we not tinker

\footnotetext{
${ }^{54}$ Stanley Milgram, "The Perils of Obedience" (1974), 6.

55 See Robert Jackall, Moral Mazes: The World of Corporate Managers (Oxford: Oxford University Press, 1988). Forge, 1996)

${ }^{56}$ See George Ritzer, The McDonaldization of the Society, revised edition (California: Pine

${ }^{57}$ Cf. Max Horkheimer, "The State of Contemporary Social Philosophy and the Tasks of an Institute for Social Research," in Critical Theory and Society: A Reader, ed. by Stephen Eric Bronner and Douglas Kellner (New York: Routledge, 1989).

${ }^{58}$ John Sniegocki, Catholic Social Teaching and Economic Globalization: The Quest for Alternatives (Wisconsin: Marquette University Press, 2009).

${ }^{59}$ The issue is not so much the greedy businessman but the capitalist system from which even the businessmen are entrapped and rendered powerless.
}

(C) 2015 Franz Giuseppe F. Cortez http://www.kritike.org/journal/issue 17/cortez december2015.pdf ISSN 1908-7330 


\section{Critical Business Ethics}

with this internal logic? In our age when young generation would always find ways, should we not lose hope that even internal logic can be manipulated internally? Will not new combinations emerge when we tinker enough?

For example, did Malaysia, Singapore, and China tamper with the very logic of capitalism? There is also the case of Joseph Stiglitz, the economist who resigned from the World Bank. Even if he was scandalized with the globalizers, he was also at the same time hopeful about globalization. ${ }^{60}$ And what about the efforts of a Muhammad Yunus to resist World-Bank invasion, raise Grameen Bank, and in the process, defied "discourses embedded within capitalism while not completely abandoning the capitalist structure"? ${ }^{61}$ Of course, Yunus is not without its share of rightful criticisms, but it is worthwhile to note that Grameen Bank is considered as a potential alternative by some scholars in the tradition of critical business ethics and critical organization. ${ }^{62}$

\section{The Challenge of Auto-criticism}

Critical business ethics may easily be dismissed as just another variation in a plethora of approaches. Worse, it may be conceived by business students, teachers, and professionals as "another 'truth' that fails to encompass the complexities of organizations and management" 63 or that simply becomes insensitive "to the more mundane world of management and organization." 64 And if that is the case, scholars of critical business ethics must turn to themselves for auto-criticism. What could be the ethics of the very act of criticism?

The radical educator, bell hooks, once said: "When we write about the experiences of a group to which we do not belong, we should think about the ethics of our action, considering whether or not our work will be used to

${ }^{60}$ See Joseph Stiglitz, Globalization and Its Discontents (New York: W.W. Norton and Company, 2002).

${ }^{61}$ Sokthan Yeng, "The Grameen Bank and Capitalist Challenges," in Cutting-Edge Issues in Business Ethics, ed. by Molly Painter-Morland and Patricia Werhane (Dordrecht: Springer, 2008), 75.

62 See Martin Parker, Valerie Fournier and Patrick Reedy, The Dictionary of Alternatives: Utopianism and Organization (London: Zed Books, 2007), 117-119; also, Raza A. Mir, Ali Mir and Punya Upadhyaya, "Toward a Postcolonial Reading of Organizational Control," in Postcolonial Theory and Organizational Analysis: A Critical Engagement, ed. by Anshuman Prasad (New York: Palgrave MacMillan, 2003).

${ }^{63}$ Jackie Ford, Nancy Harding and Mark Learmonth, "Who is it that would make Business Schools more Critical? Critical Reflections on Critical Management Studies," British Journal of Management, 21:1 (2010), s71-s81.

${ }^{64}$ Mats Alvesson and Hugh Willmott, "On the Idea of Emancipation in Management and Organization Studies," Academy of Management Review, 17:3 (1992), 434.

(c) 2015 Franz Giuseppe F. Cortez

http://www.kritike.org/journal/issue 17/cortez december2015.pdf

ISSN 1908-7330

(cc) BY-NC-ND 
reinforce and perpetuate domination." 65 Paraphrasing hooks, when scholars of critical business ethics (many are outsiders to business) make judgments about the experiences of the business people, they should also think about the ethics (and politics) of making judgments lest their work may unintentionally contradict itself: dominating, subordinating, and oppressive masquerading as emancipatory, liberative, and critical.

One is reminded here of Friedrich Nietzsche's quip that "a great truth wants to be criticized, not idolized." 66 Or more relevant and fitting are the words of Theodor Adorno in Negative Dialectics: "No theory today escapes the marketplace. Each one is offered as a possibility among competing opinions; all are put up for a choice; all are swallowed." ${ }^{67}$ And is it not that critical business ethics is also a kind of theory-construction that does not exist in a vacuum and does not escape the marketplace? Thus, Martin Parker explains that the work of the negative dialectician consists in "an endless rehearsal of being critical of being critical." 68

\section{Final Words}

The scholars of critical business ethics commonly operate within the institution that it resists. To a certain extent, they also lean on the corporations, business schools, and capitalist programs that they intend to problematize and challenge. I do not see that a combative declaration of independence from these interest groups is a prudent step towards emancipation. Critical business ethics is born from the womb of the business academic institutions. Thus, it has to continue its work of immanent critique or criticism from within. 69

The Brazilian philosopher and educator Paulo Freire says that critical educators must learn to play around the system: one foot outside and one

${ }^{65}$ Bell Hooks, Talking Back: Thinking Feminist, Thinking Black (London: Sheba Feminist Publishers, 1989), 43.

${ }^{66}$ Quoted in Martin Jay, The Dialectical Imagination: A History of the Frankfurt School and the Institute of Social Research 1923-1950 (London: Heinemann Educational Books Ltd., 1973), 50.

${ }^{67}$ Theodor Adorno, Negative Dialectics. Quoted in Michael Peters, Mark Olssen, and Colin Lankshear, "Introduction: Futures of Critical Theory - Dreams of Difference," in Futures of Critical Theory: Dreams of Difference, 2.

68 Parker, "Business, Ethics and Business Ethics," 210.

69 "Immanent critique involves critically questioning the norms and values found within existing social arrangements and institutions in order to expose contradictions and tensions between ideas and practices which often lead to unacknowledged forms of oppression. Once such contradictions and tensions are exposed, historically possible opportunities for emancipation and social change can then be identified and put into practice." Chamsy el-Ojeili and Patrick Hayden, Critical Theories of Globalization (New York: Palgrave MacMillan, 2006), 7.

(C) 2015 Franz Giuseppe F. Cortez http://www.kritike.org/journal/issue 17/cortez december2015.pdf

ISSN 1908-7330

(cc) BY-NC-ND 


\section{Critical Business Ethics}

foot within the system. ${ }^{70}$ Probably, it is because the system itself provides small spaces and openings to resist, to question, and to emerge. Having said this, critical business ethics has to contend incessantly with the persuasive force of the dominant discourse. And whatever small influence it can impart, it should always be taken as a small but necessary contribution in our quest for a more humane, just, and emancipatory social order. I think that even if there were difficulties that a critical approach would confront, it would always remain a worthwhile endeavor. Thus, those who will teach Business Ethics and Social Responsibility must create opportunities and look for small pockets and openings when and where an alternative approach may thrive.

Department of Philosophy, University of Santo Tomas, Philippines

\section{References}

Alvesson, Mats and Hugh Willmott, "On the Idea of Emancipation in Management and Organization Studies," Academy of Management Review, 17:3 (1992).

Bolaños, Paolo A., "What is Critical Theory? Max Horkheimer and the Makings of the Frankfurt School," in Mabini Review, 2:1 (2013).

Bronner, Stephen Eric, Critical Theory: A Very Short Introduction (New York: Oxford University Press, 2011).

Brookfield, Stephen, The Power of Critical Theory for Adult Learning and Teaching (New York: Open University Press, 2005).

Burbules, Nicholas and Rupert Berk, "Critical Thinking and Critical Pedagogy: Relations, Differences and Limits," in Critical Theories in Education, ed. by Thomas S. Popkewitz and Lynn Fendler (New York: Routledge, 1999).

Christensen, Lois and Jerry Aldridge, Critical Pedagogy for Early Childhood and Elementary Educators (Dordrecht: Springer, 2013).

Clegg, S., M. Kornberger and C. Rhodes, "Organizational ethics, decision making, undecidability," in Sociological Review, 55:2 (2007).

Dean, F. Peter, "Thinking Critically About Business Ethics," in Journal of College Teaching and Learning, 1:4 (2004).

Eagleton, Terry, Why Marx was Right? (New Haven: Yale University Press, 2011).

el-Ojeili, Chamsy and Patrick Hayden, Critical Theories of Globalization (New York: Palgrave MacMillan, 2006).

${ }^{70}$ Paulo Freire and Ira Shor, A Pedagogy for Liberation: Dialogues on Transforming Education (Connecticut: Bergin and Garvey Publishers, Inc., 1987).

(c) 2015 Franz Giuseppe F. Cortez

http://www.kritike.org/journal/issue 17/cortez december2015.pdf

ISSN 1908-7330

(cc) BY-NC-ND 
Engelbrecht, Schalk, "Radical Business Ethics: A Critical and Postmetaphysical Manifesto," in Business Ethics: A European Review, 21:4 (October 2012).

Ford, Jackie, Nancy Harding, and Mark Learmonth, "Who is it that would make Business Schools more Critical? Critical Reflections on Critical Management Studies," British Journal of Management, 21:1 (2010).

Francis, Evangelii Gaudium, Apostolic Exhortation of the Holy Father Francis to the Bishops, Clergy, Consecrated Persons, and the Lay Faithful on the Proclamation of the Gospel in Today's World (2013).

Freeman, R. Edward, Foreword to Business Ethics and Continental Philosophy, ed. by Mollie Painter-Morland and Rene ten Bos (Cambridge: Cambridge University Press, 2011).

Freire, Paulo and Ira Shor, A Pedagogy for Liberation: Dialogues on Transforming Education (Connecticut: Bergin \& Garvey Publishers, Inc., 1987).

Hooks, Bell, Talking Back: Thinking Feminist, Thinking Black (London: Sheba Feminist Publishers, 1989).

Horkheimer, Max, "The State of Contemporary Social Philosophy and the Tasks of an Institute for Social Research," in Critical Theory and Society: A Reader, ed. by Stephen Eric Bronner and Douglas Kellner (New York: Routledge, 1989).

Islam, Gazi, "Ethical Issues of Reification and Recognition in HRM: A Critical Social Theory Perspective," in Business Ethics: A Critical Approach, Integrating Ethics Across the Business World, ed. by Patrick O'Sullivan, Mark Smith, and Mark Esposito (London: Routledge, 2012).

Jackall, Robert, Moral Mazes: The World of Corporate Managers (Oxford: Oxford University Press, 1988).

Jay, Martin, The Dialectical Imagination: A History of the Frankfurt School and the Institute of Social Research 1923-1950 (London: Heinemann Educational Books Ltd., 1973).

Jones, Campbell, “As if Business Ethics Were Possible, 'Within such Limits . . .,$'$ ' in Organization, 10:2 (2003).

Jones, Campbell, Rene ten Bos, and Martin Parker, For Business Ethics: A Critical Approach (London: Routledge, 2005).

Lippke, Richard, Radical Business Ethics (Lanham, MD: Rowman \& Littlefield, 1995).

Losoncz, Alpar, "Business Ethics as Critical Approach," in Society and Economy, 25:2 (2003).

Mallen, Patricia, "Bolivia's Bill to Ban Child Labor is Opposed by Child Workers," in International Business Times (28 December 2013),

$<$ http://www.ibtimes.com/bolivias-bill-ban-child-labor-opposed-childworkers-president-evo-morales-delays-vote-january $>, 23$ October, 2014.

(C) 2015 Franz Giuseppe F. Cortez http://www.kritike.org/journal/issue 17/cortez december2015.pdf ISSN 1908-7330 
McLaren, Peter, Life in Schools: An Introduction to Critical Pedagogy in the Foundations of Education, 3rd ed. (New York: Longman, 1997).

Milgram, Stanley, Obedience to Authority (New York: Harper \& Row, 1974).

Mir, Raza A., Ali Mir, and Punya Upadhyaya, "Toward a Postcolonial Reading of Organizational Control," in Postcolonial Theory and Organizational Analysis: A Critical Engagement, ed. by Anshuman Prasad (New York: Palgrave MacMillan, 2003).

Naude, Piet, "In defence of partisan justice: What can African business ethics learn from John Rawls?" in African Journal of Business Ethics, 2:1, (2007).

Nissenbaum, Helen, "Should I Copy My Neighbor's Software?" in Computers, Ethics, and Social Responsibility, ed. by D. Johnson and H. Nissenbaum (New Jersey: Prentice Hall, 1995).

Painter-Morland, Mollie and Rene ten Bos, eds., Ethics and Continental Philosophy (Cambridge: Cambridge University Press, 2011).

Parker, Martin, "Business, Ethics and Business Ethics: Critical Theory and Negative Dialectics," in Studying Management Critically, ed. by Mats Alvesson and Hugh Willmott, (London: SAGE Publications, 2003).

Parker, Martin, Valerie Fournier, and Patrick Reedy, The Dictionary of Alternatives: Utopianism and Organization (London: Zed Books, 2007).

Peckham, Irvin, Going North, Thinking West: The Intersections of Social Class, Critical Thinking, and Politicized Writing Instruction (Utah: Utah State University Press, 2010).

Peters, Michael, Mark Olssen, and Colin Lankshear, eds., Futures of Critical Theory: Dreams of Difference (Lanham: Rowman \& Littlefield Publishers, Inc., 2003).

Prasad, Ajnesh and Albert J. Mills, "Critical Management Studies and Business Ethics: A Synthesis and Three Research Trajectories for the Coming Decade," in Journal of Business Ethics, 94 (2010).

Ritzer, George, The McDonaldization of the Society, revised edition (California: Pine Forge, 1996).

Sims, Ronald, Teaching Business Ethics for Effective Learning (Connecticut: Quorum Books, 2002).

Sniegocki, John, Catholic Social Teaching and Economic Globalization: The Quest for Alternatives (Wisconsin: Marquette University Press, 2009).

Stiglitz, Joseph, Globalization and Its Discontents (New York: W.W. Norton \& Company, 2002).

Swinyard, W. R., H. Rinne and A. Keng Kau, "The Morality of Software Piracy: A Cross-Cultural Analysis," in Journal of Business Ethics, 9 (1990).

Tallack, Douglas, ed., Critical Theory: A Reader (New York: Harvester, 1995).

(c) 2015 Franz Giuseppe F. Cortez

http://www.kritike.org/journal/issue 17/cortez december2015.pdf

ISSN 1908-7330

(cc) BY-NC-ND 
ten Bos, Rene and Hugh Willmott, "Towards a Post-dualistic Business Ethics: Interweaving Reason and Emotion in Working Life," in Journal of Management Studies, 38:6 (September 2001).

Wray-Bliss, Edward, "Abstract Ethics, Embodied Ethics: The Strange Marriage of Foucault and Positivism in Labour Process Theory," in Critical Management Studies: A Reader, ed. by Christopher Grey and Hugh Willmott (Oxford: Oxford University Press, 2005).

, "Business Ethics," in Key Concepts in Critical Management Studies, ed. by Mark Tadajewski, Pauline Maclaran, Elizabeth Parsons, and Martin Parker, (Los Angeles: SAGE, 2011).

Yeng, Sokthan, "The Grameen Bank and Capitalist Challenges," in CuttingEdge Issues in Business Ethics, ed. by Molly Painter-Morland and Patricia Werhane (Dordrecht: Springer, 2008). 